\title{
DEVELOPMENT AND PERFORMANCE OF THE PEPPER INDUSTRY IN MALAYSIA: A CRITICAL REVIEW
}

\author{
Harry Entebang* \\ Universiti Malaysia Sarawak \\ Swee-Kiong Wong \\ Universiti Malaysia Sarawak \\ Zehnder Jarroop Augustine Mercer \\ Malaysian Pepper Board
}

\begin{abstract}
The National Commodity Policy 2011-2020 was developed to increase the national income by harnessing the potential of commodity export revenues. Despite continuous efforts implemented by various related agencies, the overall performance of major commodities, particularly pepper, remains unsatisfactory. Regarded as a sought-after 'king of spices', pepper has become one of the most prized and important commodities traded globally. This paper highlights the development and performance of the pepper industry in Malaysia and discusses practical strategies and recommendations to transform the pepper industry. Besides conducting interviews with the industry experts to gain first-hand information, content and thematic analysis was employed based on secondary data research in this study. The findings of the study show that even though pepper is mostly used in food-related industries, its potential in pharmaceutical and cosmeceutical sectors remains underexplored. Globally, the overall supply and demand of pepper continue to increase, though the demand has recently exceeded supply. However, continuous new planting and farm expansion initiatives by major producers caused the total global pepper supply to exceed consumption in 2018. In fact, pepper prices have declined more than $70 \%$ since 2015 , which affected the overall household income of the rural community engaged in pepper farming. While experiencing low prices, smallholder pepper farmers and the industry continue to struggle with low domestic consumption, low production, higher cost of farm inputs, lack of extension services, low impact of research, development and innovation, ageing farming population, intense competition from other producing countries, low prices for quality pepper, limited subsidy to support continuous farming, pepper-related diseases, lack of new technology, and poor investment in downstream activities. Given this, the performance of the Malaysian pepper industry has fallen below expectations.
\end{abstract}

Keywords: Sarawak Pepper, Challenges, Competitiveness and Prospects.

Received: 3 February 2020

Accepted: 11 September 2020

\footnotetext{
- Corresponding author: Faculty of Economics and Business, Universiti Malaysia Sarawak, 94300 Kota Samarahan, Sarawak, Malaysia; Tel.: 6082-584298; Email: eharry@unimas.my
} 


\section{INTRODUCTION}

The agricultural sector continues to play a pivotal role in socio-economic development in Malaysia, particularly among rural communities. Despite an increase in absolute value, the share of the agricultural sector in Gross Domestic Products (GDP) has been declining (Dardak, 2015). Nonetheless, the sector continues to provide employment and income opportunities to people in rural areas.

As one of the major producers and exporters of several major commodities such as palm oil, rubber, timber, cocoa and pepper, various strategic efforts, including the development of the National Commodity Policy (NCP) 2011-2020, have been carried out to enhance the competitiveness and sustainability of these commodities (Ministry of Primary Industries and Commodities [MPIC], 2012). However, higher production costs, labour constraint, stiff competition market (MPB, 2017), and political forces including a move initiated by the European Parliament (EP) to ban the use of palm oil for the production of biofuels in the European Union (EU) by 2020 aimed to stop the deforestation of rainforests mainly in Indonesia and Malaysia (see Ooi, 2019) have eventually caused the overall performance both in terms of sustainable production and export of these commodities remains highly challenging. For instance, Malaysia was once the fourth largest producer of pepper in the world, but this status had dropped drastically to the seventh world largest pepper producer in the world in 2017 (IPC, 2018b). Given this, several approaches have been outlined by the Ministry of Primary Industries (previously named as MPIC) to ensure that the commodity sector continues to be competitive and relevant in the ever-changing market environment. These approaches include strengthening the sector through modernization of production technology, developing more value-added products through effective Research, Development \& Innovation (R\&D\&I) initiatives, strengthening current market share while exploring new market opportunities, and enhancing smallholders' capability via effective utilization of modern technology. Despite the overall growth of major commodities in Malaysia, the overall development and performance of the pepper industry in particular is still below expectations mainly due to technical inefficiencies, improper farm management, and misallocation of inputs that have led to poor yield production (Rosli, Radam, \& Rahim, 2013).

This paper specifically reviews, highlights, and discusses the development and performance of the pepper industry in Sarawak, Malaysia. The key focus is on the issues and challenges facing the performance of the pepper industry both at the upstream and downstream levels, including the export performance of Sarawak Pepper * globally. In line with Porter's views on competitiveness and attractiveness of an industry (Porter, 1980), it was postulated that the competitiveness and attractiveness of the pepper industry in Malaysia has been undermined by several forces, including the adoption of ineffective policies by the government over the years that have caused insufficient financial allocations to meet development needs along with operational initiatives and challenges faced by the industry in the international market (MPB, 2016 b \& 2017). A continuous attack by pepper-related diseases, low pepper prices, lack of manpower to carry out effective extension services, lack of impactful research, development and

\footnotetext{
* Sarawak Pepper has been registered under Geographic Indication (GI) with the Intellectual Property Corporation of Malaysia (MyIPO) on 4 November 2003. Accounting for $98 \%$ of pepper production in Malaysia, Sarawak pepper is exported globally by Malaysian exporters via Sarawak.
} 
innovation (R\&D\&I) initiatives and insufficient market promotion activities, high cost of farm inputs, and stiff competition posed by other major producing countries have eventually reduced the attractiveness and competitiveness of Sarawak Pepper (Khalid, Wong, \& Alias, 2007). Suggestions on ways forward to ensure the industry remains relevant and competitive in the future are provided in the final section of the paper.

\section{PEPPER CULTIVATION IN MALAYSIA}

As postulated by Janvry and Sadoulet (2010), agricultural growth has long been recognized as an important instrument for poverty reduction. The study shows that rural poverty reduction has been closely associated with the growth in agricultural yields and labour productivity. In fact, the power of agriculture comes not only from its direct poverty reduction effect but also from its potentially strong growth of spillover effects on the rest of the economy (Janvry \& Sadoulet, 2010).

Pepper (Piper nigrum) has been regarded as the most precious sought-after king of spices and is one of the oldest commodities traded in the world. It is reputed to have medicinal properties, which further adds to its allure and value as a spice. In Malaysia, pepper cultivation was started in Langkawi island in 1619. However, it became one of the major crops cultivated in Sarawak by the Hakka Chinese community in Bau district in the 1840s (Sim \& Paulus, 2011). To date, the contribution of pepper in the national economy, though trivial, is one of the most important rural economic activities, particularly in Sarawak. In fact, the rise of the pepper industry in Sarawak started in the late 1970s through early 1990s. Because of its market and export potential, pepper production has become one of the main agricultural activities pursued by rural communities and one of the commodities capitalized by the government to reduce poverty rate amongst the rural communities.

Currently, the industry attracts about 33,695 smallholder pepper farmers nationwide, with about $98 \%$ of them cultivating pepper in Sarawak. Notably, $90 \%$ of the pepper produced is for the export market, though there is slight increase in domestic consumption of pepper in the country. Three divisions in Sarawak, namely Sarikei, Betong, and Serian, are the biggest pepper producing areas and account for about $61 \%$ of the total production area of 17,087 ha in 2017. Nonetheless, the total farm size has significantly reduced from 13,849 ha in 1980 to 11,408 ha in 1990 due to the low pepper prices (International Pepper Community [IPC], 2018a). After 1985, farm size gradually increased to 14,174 ha in 2010 , sparked by higher pepper prices, and continued to grow up until 2015. This may suggest that the total farm size operated by smallholders has been influenced by the fluctuation of pepper prices over the years. Despite this, the global demand for pepper showed a consistent growth trajectory between 2010 and 2017 at a Compound Annual Growth Rate (CAGR) of 5.09\% (Pemandu Associates, 2018). In fact, the demand for pepper is expected to increase in tandem with the rise in the world's population to 9.8 billion by 2050 (Chen \& Mansel, 2017).

\subsection{Production, Supply and Demand of Pepper Globally}

Malaysia has been involved in pepper trading activity since the early 1970s. According to an IPC report released in October 2018, Malaysia ranked seventh in global pepper production in 2017 
with a total production of 23,500 metric tonnes after Vietnam, which spearheaded pepper production in the world with a production of 200,000 metric tonnes. This is followed by Indonesia (70,000 metric tonnes), Brazil (65,000 metric tonnes), India (57,000 metric tonnes), China (34,500 metric tonnes), and Sri Lanka (29,546 metric tonnes), respectively.

Table 1 depicts the total pepper production in major pepper producing countries in 2017. Except for Malaysia, the volume of pepper production increased in 2017 in all major pepper producing countries, especially in Vietnam and Brazil.

Over the past few years, the overall supply and demand of pepper has continued to increase gradually in the global market causing the demand to exceed the supply. The growing demand in pepper is mainly attributable to the increasing demand of pepper in the food industry for seasoning, preservative, and garnish in addition to its function as an essential oil in perfumes, cosmetics, and pharmaceutical industries (Khalid et al., 2007; Wong, 2007).

Table 1: World Pepper Production by Major Pepper Producing Countries in 2017

\begin{tabular}{cc}
\hline \hline Country & Total Volume of Pepper Production (Metric tonnes) \\
\hline Vietnam & 200,000 \\
\hline Indonesia & 70,000 \\
\hline Brazil & 65,000 \\
\hline India & 57,000 \\
\hline China & 34,500 \\
\hline Sri Lanka & 29,546 \\
\hline Malaysia & 23,500 \\
\hline \hline
\end{tabular}

Source: IPC, $2018 \mathrm{~b}$

However, a continuous new planting and farm expansion initiative by major producer countries caused the total global supply of pepper to exceed consumption in 2018. In 2018, for instance, the total global demand for pepper was estimated at approximately 457,000 metric tonnes, while the overall production was estimated at 575,000 metric tonnes, with an annual demand growth rate of $2.4 \%$ (Gulick, 2018). This suggests that the consumption is well below production level. Gulick (2018) further postulated that the global pepper stocks would continue to increase. Even though new pepper planting has remained stagnant for the time being, pepper production is expected to increase due to the new expansion that took place between 2015 to 2017 in Vietnam, Brazil, China, and Cambodia. Consequently, the excess supply from the increased production will cause a further increase in global stocks, resulting in a continuous downward price pressure. Unless more innovation is introduced and promoted to increase the alternative use of pepper, more time might be needed before the supply again meets with the demand in the global pepper market.

\subsection{Pepper Planted Area}

In Malaysia, pepper is cultivated on an estimated area of 17,087 hectares in 2017 by 33,695 farmers who live mostly in the interior areas, and almost $98 \%$ of the cultivation is in Sarawak. Pepper farms in Sabah and Peninsular Malaysia make up the remaining 2\% of the total planted area in Malaysia (Malaysian Pepper Board [MPB], 2018b). 
Table 2: Pepper Planted Area

\begin{tabular}{clccc}
\hline \hline \multirow{2}{*}{ No. } & \multirow{2}{*}{ Region } & \multicolumn{3}{c}{ Planted Area (ha) } \\
\cline { 3 - 5 } & & $\mathbf{2 0 1 5}$ & $\mathbf{2 0 1 6}$ & $\mathbf{2 0 1 7}$ \\
\hline 1. & Sarawak & 16,092 & 16,516 & 16,798 \\
\hline 2. & Sabah & 35 & 16 & 33 \\
\hline 3. & Peninsular Malaysia & 206 & 236 & 256 \\
& & 16,333 & 16,768 & 17,087 \\
\hline \hline
\end{tabular}

Source: MPB, 2018b

Table 2 shows the total planted area of pepper in Malaysia between 2015 and 2017. As depicted in Table 2, the total pepper planted area in Malaysia increased by 1.9\% in 2017 from 16,768 hectares in 2016.

\subsection{Production and Processing of Sarawak Pepper}

In Malaysia, harvested pepper can be processed into black and/or white pepper. Black pepper is produced from the fresh ripe berries plucked from the pepper vine, which is commonly dried under the sun for 3-4 days. At times, this process may take longer time depending on the weather conditions. When the price differential between black and white pepper is perceived to be significant, pepper farmers may select relatively bigger than the standard size of pepper berries to go for white pepper production. Those selected pepper berries will be transferred into a nylon gunny sack and kept in running river water to remove the pericarp from the berries (Wong, 2007). The process of soaking, cleaning, and then drying the pepper will normally take about two weeks before white pepper is produced.

In terms of pepper production, Malaysia registered an increase of $2.13 \%$ from 23,000 tonnes in 2016 to 23,500 tonnes in 2017 (IPC, 2018a). The increase was partly due to the expansion of pepper farms throughout the region fostered by temporary higher pepper prices in 2015 . Figure 1 depicts pepper production in Malaysia from 2015 to 2017.

Notably, an oversupply of pepper from Vietnam and Brazil has caused pepper prices to decline more than $60 \%$ in Malaysia since 2015 (MPB, 2017), which has affected the overall household income of the rural pepper farming community. By the end of 2018, pepper prices had dropped more than $70 \%$ (MPB, 2018a). This indeed has posed a great challenge in terms of poverty eradication efforts carried out by the government, particularly in Sarawak. 
Figure 1: Pepper Production in Malaysia, 2015-2017

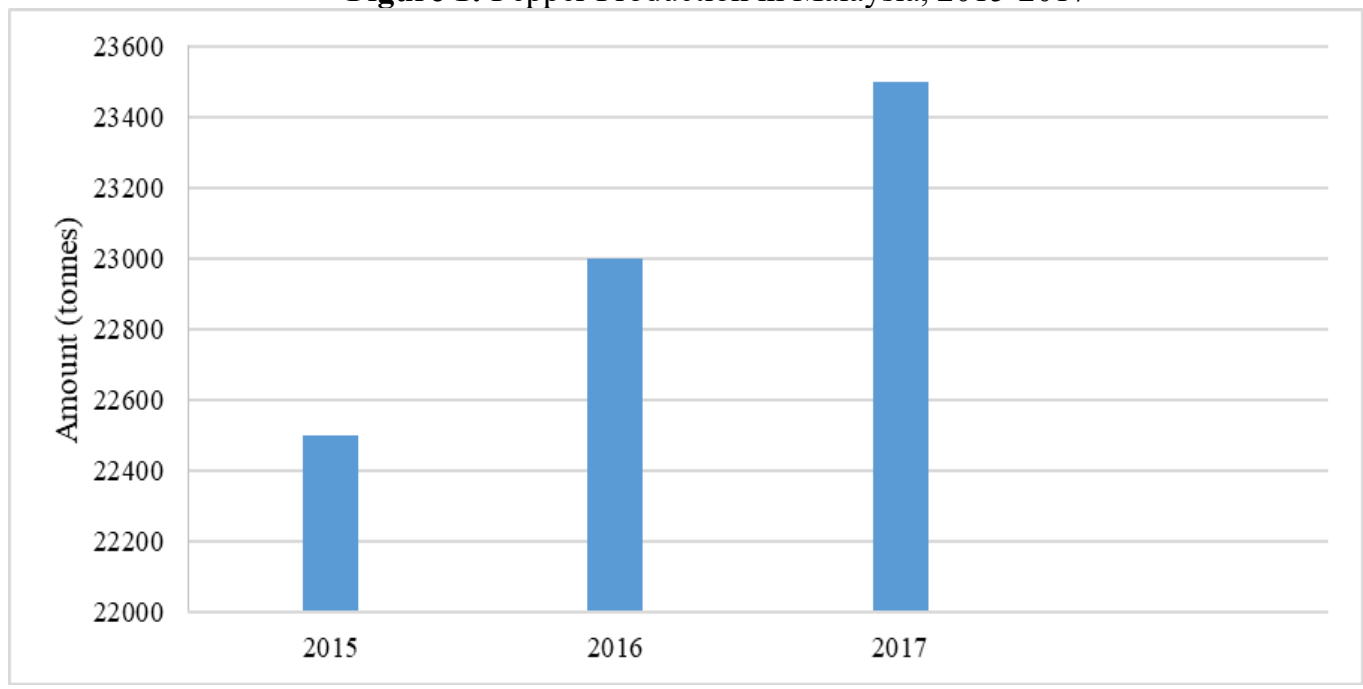

Source: IPC, 2018a

\subsection{Farm Size and Yield}

In general, all pepper farmers in Malaysia are smallholders who hold an average farm size of 0.1$0.2 \mathrm{ha}$. Given the farm size of $0.2 \mathrm{ha}$ and with an average yield of $2.6 \mathrm{~kg}$ per pepper vine, a single pepper farming family may produce merely just over one tonne (1.04 tonnes) of pepper harvest a year (Awit, 2017). In fact, the reason for having a smallholding of farm size is partly due to the lack of land resources suitable for pepper cultivation. Land has becoming scarce as the crop has to compete mainly with other economic crops such as oil palm and rubber. This is particularly true when pepper prices remain low and are perceived by farmers as unattractive. Farmers may quickly venture into other commodities, especially oil palm, without proper assessment in terms of start-up capital and labour requirements to gain higher return. In addition, pepper cultivation is very labour intensive. Thus, unless mechanization of pepper harvesting takes place, most farmers cannot afford to cultivate pepper in a big farm, as ripe pepper berries need to be harvested quickly to avoid loss of yield during harvesting season. Pepper is also susceptible to various disease attacks. Small farm size may also lead to chances of giving up the farm for other cash crops that are easier, particularly when pepper vines are infested with disease.

\subsection{Export of Sarawak Pepper}

As the world's largest pepper producer, pepper production in Vietnam has continued to increase, from 180,000 metric tonnes in 2016 to 205,000 metric tonnes in 2018 (IPC, 2018b). On the other hand, Malaysia managed to export only 11,640 metric tonnes of pepper against its total production of 23,500 metric tonnes valued at RM309 million in 2017 to various destinations around the globe. Notably, total exports have dropped by 559 metric tonnes or RM181 million, from 12,199 metric tonnes (RM490 million) recorded in 2016. This is due to excessive global stock levels, which has subsequently pushed the pepper prices further down (Gulick, 2018) as 
major pepper suppliers decided to drop their prices lower than the price of Sarawak Pepper. Figure 2 depicts the export performance of Sarawak Pepper in 2015-2017.

Figure 2: Export of Sarawak Pepper, 2015-2017

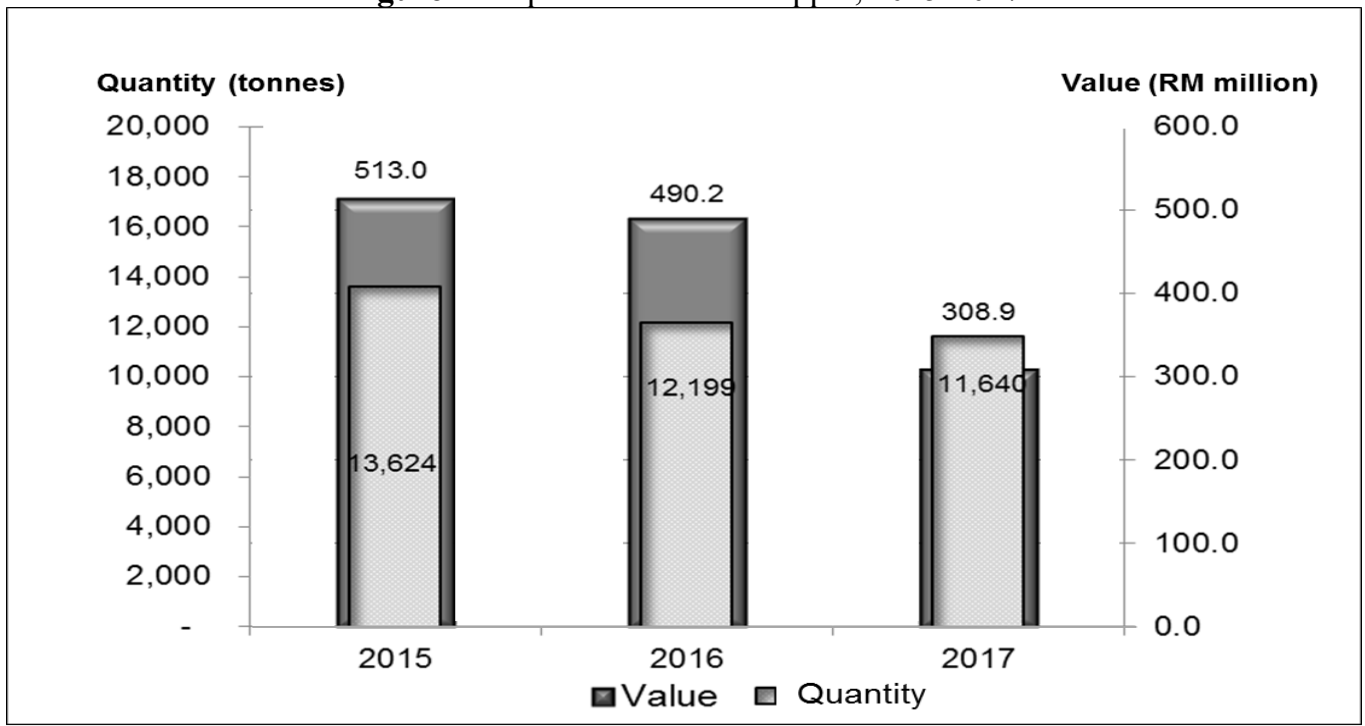

Source: MPB, 2017

Sarawak Pepper is exported to several countries around the world, especially Japan. Japan is the largest importer of Sarawak Pepper, with the volume of imports around 2,963 metric tonnes or equivalent to $25 \%$ of the total exports from Malaysia in 2017, followed by China and Vietnam accounting, respectively, for $19 \%$ and $13 \%$ of the total exports in the same year. Malaysia also exports Sarawak Pepper to other countries in Asia, including Korea, and Taiwan, and several destinations in Europe, Australia, and New Zealand. Figure 3 depicts the major export destinations of Sarawak Pepper. 
Figure 3: Malaysia's Exports by Destination in 2017

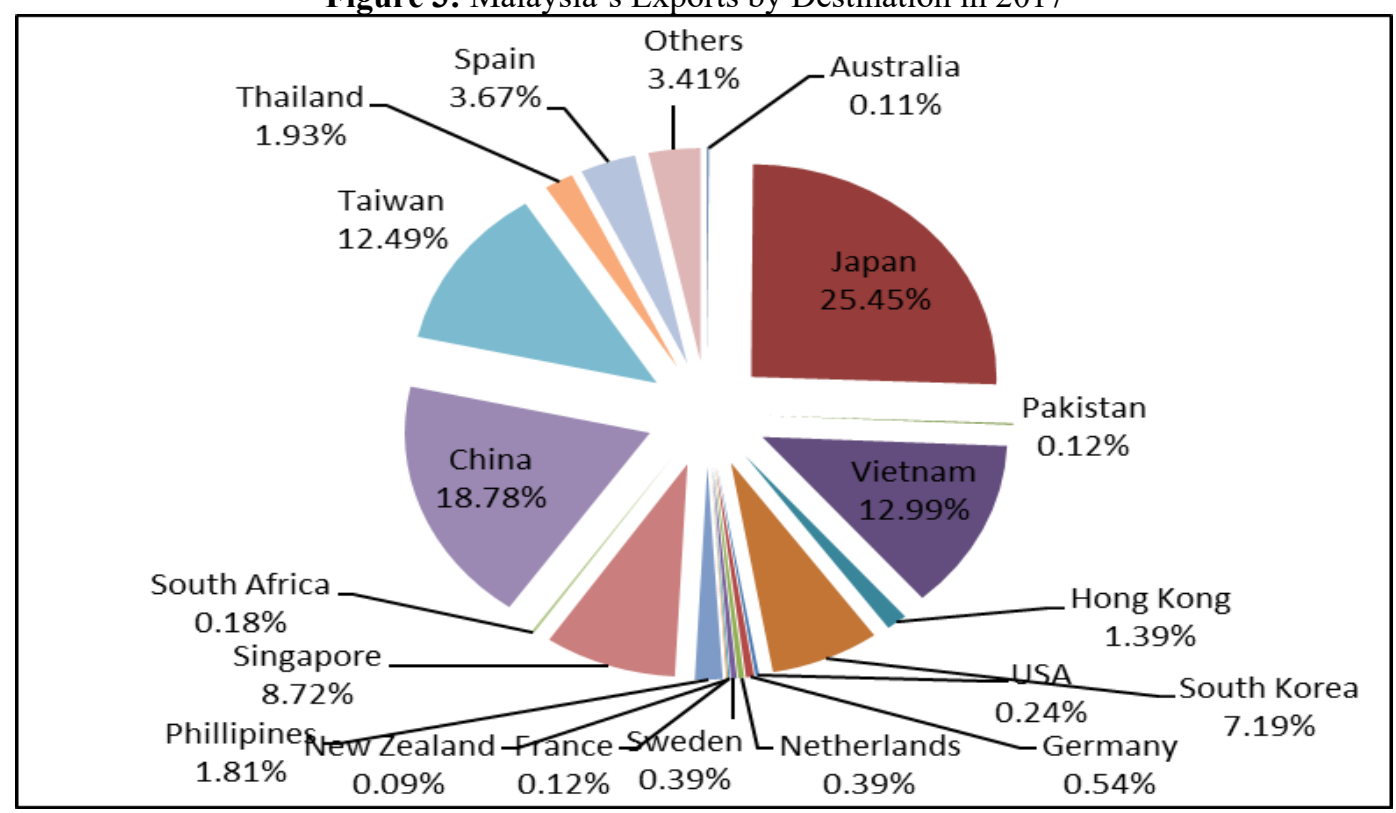

Source: Department of Statistics Malaysia, 2017

\subsection{Manpower}

Pepper is mostly cultivated by smallholders. As of 2017, it was estimated that 33,695 farming families were involved in pepper cultivation throughout the country (MPB, 2018b). The breakdown of the number of farmers involved in pepper farming by region in 2017 is 33,306 in Sarawak, 169 in Peninsular, and 220 in Sabah. On average, the size of a pepper farm is 0.5 hectares in Sarawak, 1.5 hectares in Peninsular, and 0.2 hectares in Sabah. Given the nature of pepper planting, pepper farming in Malaysia particularly in Sarawak has normally been confined to family members only, and the use of foreign workers has been very minimal partly because labour costs are getting more expensive, particularly in Sarawak. In search of better job opportunities, the migration among the youths from rural to urban areas has increased gradually. Hence, in the long run, this may affect the development of the pepper industry in Sarawak.

Nevertheless, manpower utilization or the nature of employment in pepper farming is quite different in Peninsular Malaysia, as pepper cultivation there is more entrepreneurially driven. Farms in Peninsular Malaysia tend to use more foreign workers than the farms in both Sabah and Sarawak (Awit, 2017). The number of workers hired, as of December 2016, is 109 people, suggesting that growing pepper is an owner operation enterprise. Table 3 depicts the manpower/workers engaged in the pepper industry in Malaysia. 
Table 3: Manpower / Employment Opportunities in Pepper Sector in Malaysia

\begin{tabular}{|c|c|c|c|c|c|c|c|c|c|}
\hline \multirow[b]{2}{*}{$\begin{array}{l}\text { Area } \\
\text { (ha) }\end{array}$} & \multirow[b]{2}{*}{$\begin{array}{l}\text { Total Workers } \\
\text { Requirement }{ }^{1}\end{array}$} & \multicolumn{2}{|c|}{ No. of Owners } & \multicolumn{2}{|c|}{$\begin{array}{c}\text { Hired Local } \\
\text { Workers }\end{array}$} & \multicolumn{3}{|c|}{ Hired Foreign Workers } & \multirow[b]{2}{*}{ Total } \\
\hline & & 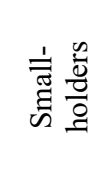 & 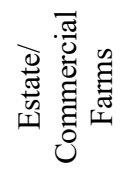 & 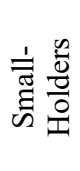 & 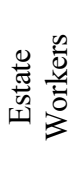 & 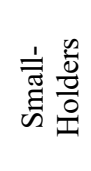 & 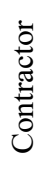 & 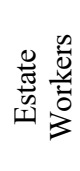 & \\
\hline 16,768 & 33,536 & 33,688 & 7 & 2 & 5 & 102 & - & - & 109 \\
\hline
\end{tabular}

Note: ${ }^{1}$ Ratio 1 ha: 2 persons

\subsection{Research \& Development \& Innovation (R\&D\&I)}

Research, Development, \& Innovation (R\&D\&I) plays a vital role in shaping the landscape of the pepper industry in Malaysia (Eng \& Gumbek, 2007; Paulus, 2007). Early research on pepper was undertaken and promoted by the Agriculture Research Centre (ARC), a center under the purview of the Department of Agriculture, Sarawak, until early 2010. To spearhead this effort, Research and Development (R\&D) programmes and activities have been focusing on strengthening pepper biotechnology, pepper agronomy, downstream research, and food product development. Currently, research activities are mostly fundamental and ongoing. Some of these developments are highlighted below.

\subsubsection{Pepper Biotechnology Research}

Phytophthora foot rot caused by Phytophthora capsici remains one of the most devastating diseases of black pepper in Malaysia (Kueh, 1979; Paulus, Sim, Eng, Megir, \& Rosmah, 2011). For instance, a total of approximately 365,000 pepper vines in Sarawak were attacked by Phytophthora- and Fusarium-related diseases from November 2017 until May 2018, a period where heavy rain occurred continuously in Sarawak (Awit, 2018). Recognising this, a biotechnological approach of research aiming to improve the growth and yield of black pepper remains one of the key emphases to better control pests and diseases through integration of a biological approach. In addition, the biotechnological research also focuses on the fundamental study of pepper DNA, aiming to discover a disease-resistance gene and the fruit ripening genes (Khew, Lau, Evy, \& Haroun, 2015; Lau, Hwang, Lily, \& Paulus, 2013).

\subsubsection{Pepper Agronomic Research}

Research into pepper agronomics focuses on increasing the productivity and quality of pepper through research and innovation of pepper cultivation while improving the existing pepper cultivation practices as well as developing a low-cost planting package. The invention of semiorganic fertilizer has claimed to increase pepper's yield while reducing the chances of disease attacks on pepper. It has won several local and international recognitions, including the IChemE global Award, ITEX 2016 awards, and Malaysia Technology Expo Awards (Haryani, 2016). The fertilizer comprises both inorganic and organic fertilising substances enriched with supplemental microorganisms. The nutrient content of the fertiliser is Nitrogen (15\%), Phosphorus $(5 \%)$, Potassium (14\%), Magnesium (2\%), and TE (trace elements). It increases the soil $\mathrm{pH}$ and thus 
boosts the efficiency of nutrient uptake. Such compositions also enhance the long-term retention of nutrients in the soil and improve soil and berry quality (Yap, 2015).

In addition, collaboration with other institutions in 2017 contributed to the development of a mobile application $(A P P)$ named $D R$. $L A D A$. This interactive artificial intelligence android-based mobile application was jointly developed by the MPB and Universiti Kebangsaan Malaysia (UKM) to diagnose six pests and 10 pepper diseases commonly found in Malaysia and recommends appropriate management measures to solve the problems. This mobile application inference engine utilises the forward-backward chaining methods to trigger the correct output from a decision tree inter-relating the expert rules extracted and validated by the MPB experts (Shafinah, Sahari, Sulaiman, Saif, \& Ikram, 2019).

\section{RESEARCH DESIGN}

There are several research strategies available in data collection. However, the main research strategies are experimental, survey (including use of self-completed questionnaires and interview), case study, ethnography, and action research (Groenewald, 2004). To review the pepper industry's development and performance in Malaysia, a mixed method approach was used. While carrying out a literature review on past studies, desk research was performed by mainly examining various documents, reports, and publications published by the MPB. In addition to semi-structured interview held with the management team of the organisation, a further review on data taken from the survey with farmers by the board was also carried out. The information generated was used for analysis in this study. Collected data were processed and analysed using content analysis methodology. Relevant data and information were categorized into main themes and sub-themes. A multi-strategy research or a mixed-methods design (Creswell \& Plano Clark, 2007) was adopted in this study because it helps to provide more comprehensive empirical evidence in studying the underlying subject.

\section{FINDINGS}

The development and performance of the pepper industry in Malaysia has reached a critical stage. The findings from the review of past literature, outcomes of the desk review, and feedback obtained from the survey and case study have provided new insights and established some additional evidence in the industry. In particular, the findings are derived from an analysis of the case study conducted on 48 pepper cultivators representing about $10 \%$ of the total participants of a new pepper planting programme implemented by the MPB. These farmers planted between 500 and 5,000 pepper vines during the time of the study. Building on the information gathered, we identified key challenges that have affected the performance of smallholder pepper cultivators, the implementing agency, and pepper traders and the overall development of the industry. The challenges are divided into two broad categories, namely, upstream and downstream. To ensure the industry remains attractive and competitive, some strategic directions and strategies are highlighted and proposed for consideration by the policymakers and other stakeholders. 


\subsection{Challenges in the Upstream}

Pepper planting activity remains a challenging farming activity in the rural community, particularly in Sarawak, Malaysia. Some of the challenges identified include low yield and unstable income, ageing population and lack of interest among the younger generation, higher cost of farm inputs, minimal extension services, pepper related diseases, limited subsidy and assistance, low impact of R\&D\&I, and a lack of Good Agricultural Practices (GAP).

\subsubsection{Low Yield and Unstable Income}

The average yield per hectare for pepper in Malaysia is 5.2 tonnes. This is lower than the national target of 6 tonnes (MPIC, 2012). Low yield stems from pests and disease problems, which can occur at various stages of pepper vine development. Important pests include the tingid bug (Dicronocoris hewetii), pepper weevil (Lophobaris piperis), cigarette beetle (Lasioderma serricorne), and others. Devastating diseases are Phytophthora foot rot, Fusarium sp., black berry disease, and nematodes (Eng \& Gumbek, 2007). Phytophthora foot rot has been reported to cause an annual crop loss of 5-10\% (Kueh, 1978) and up to $95 \%$ loss for individual farmers (Manohara, Mulya, \& Wahyuno, 2004). Notably, the yield of the pepper produced will also depend on the soil fertility. Unless there is a major breakthrough in pepper cultivation by using innovative technology and effective research to combat pepper-related diseases, the Malaysian pepper industry will face the great challenge of shrinking production.

Despite the above issues and challenges surrounding the development of the pepper industry, particularly in Sarawak, findings from the case study conducted on 48 out of 480 pepper farmers who had participated in a special new planting programme initiated by the MPB between 2012 and 2014 highlights that the programme has increased new pepper planting from 812 ha to 831 ha. In addition, the programme has also successfully increased pepper productivity from $2.3 \mathrm{~kg} / \mathrm{vine}$ to $2.6 \mathrm{~kg} / \mathrm{vine}$ after farmers were provided with the farm inputs showing the success of the programme. Consequently, this has increased the household income of the programme participants from RM1,341 to RM4,550 per month. Notably, an increase of household income experienced by pepper farmers at that time is due to higher pepper prices recorded during the study period. However, pepper prices started to decline abruptly after 2017 due to overproduction in Vietnam.

\subsubsection{Ageing Population and Lack of Interest among Younger Generation}

The majority of the pepper farmers are an ageing population who cultivate pepper on their Native Customary Rights (NCR) land in Sarawak, while most of their children have sought better job opportunities outside the villages. Most youths argue that employment outside the village tends to provide them with a steady monthly income compared with the unstable income caused by low productivity and a fluctuating market for most agricultural commodities. In addition, they tend to perceive pepper planting activity as hard work and have regarded it as a less glamorous economic activity. Given this, the challenge is how to attract the younger generation into the farming industry and to present pepper farming as an agribusiness activity that has an ability to generate better and steady income. In this vein, a question was asked to one of the pepper planters who has cultivated pepper in Balai Ringin, Serian. The question asked was whether she would encourage her children to continue her pepper farm, and she responded: 
"I do not want my children to continue this pepper cultivation venture as it is dirty, dangerous, and demanding. Dirty as you have constant contact with the soil and causing the fingers to turn a dark colour with the stain from the pepper when sorting the pepper berries from the stalks. It is considered 'dangerous', as most of the cases will involve the use of pesticides or weedicide. Dangerous could also refer to the unstable income, as farmers can hardly predict the prices of pepper that they cultivate, which can only be harvested after three years".

In addition, she emphasized that the processes involved in pepper cultivation is tedious due to land preparation, drainage preparation and maintenance, planting, weeding, applying fertilizer, pruning, spraying, harvesting, and processing, which is said to be demanding in its work nature (Wong, 2007).

\subsubsection{Higher Farm Costs}

Information gathered from a fieldwork survey suggests that the cost of pepper production in Malaysia remains high. In fact, it continues to increase gradually due to an increase in agricultural input costs, especially fertilizer, pesticide, and weedicide. The input cost of pepper cultivation is mainly made up of cost to purchase belian post (Eusideroxylon zwageri ironwood), fertilizer, pesticide, and weedicide. In addition, the labour cost has also become the key component of the overall production costs (Wong, 2007). At times, it is possible to obtain free new pepper cutting materials from other villagers; however, some of the farmers have started to impose a minimum charge of RM3-RM5 per cutting. The price may vary according to the market price of pepper at a particular time period. In Sarawak, the cost to start pepper cultivation up to the third year has increased significantly in the last decade. For example, the total costs including start-up capital are approximately RM10,500 per acre or RM26,000 per hectare (Awit, 2017). Given the break-even price of RM9/kg for black pepper, any farm gate price that falls below the break-even price would suggest that pepper planters will not make any gain from the activity (Awit, 2017). On the other hand, as belian post has gradually been depleting over the years, this has also contributed to a higher cost of establishing a pepper farm in the state and, hence, a more innovative way or an alternative of substituting belian post needs to be seriously considered. In fact, some farmers have opted for living post such as Gliricidia sepium and Erythrina indica as alternative support though there is limitation on this alternative. Thus, this calls for a more intensive research and development to be carried out.

\subsubsection{Minimal Extension Services}

Currently, extension services fall under the purview of the MPB. However, due to a limited number of extension staff, extension and support services provided have been minimal. The ratio between farmers and extension staff is 1:942 (Awit, 2017). Hence, the effectiveness of the extension services has become another issue. In fact, effective extension services have become more critical, especially when more farms are attacked by diseases. In addition, the ability to provide sufficient extension staff to support the development of the industry may increase the frequency and the level of knowledge transfer to the farmers. Without such improvements, the growth and competitiveness of the industry may be affected. 


\subsubsection{High Risk Factor}

A special programme was initiated by the Malaysia Pepper Board to encourage the private sector to venture into pepper planting activities in 2017. The feedback gathered suggests that the private sector views pepper cultivation as a high-risk business to pursue due to pepper-related diseases. This is further supported by the recent attack of Phytophthora foot rot and Fusarium sp. on major pepper farms in Sarikei and Betong divisions in Sarawak. In addition, the private sectors also argue that pepper prices are highly volatile compared to other cash crops, such as oil palm. In 2015, the price of black pepper climbed to RM30 per kg then gradually declined to RM7 per kg in 2019 , a drop of more than $70 \%$ in less than five years.

\subsubsection{Limited Subsidy and Assistance}

Subsidies remain a pervasive feature of agricultural policy in both developed and developing economies (see Chand \& Phillip, 2001; Amadeo, 2020). Hence, the agriculture subsidy plays a very important role in the agriculture sector in every developing country, including Malaysia. Since the formation of the MPB in 2010 as a full-fledged statutory body under the purview of the Malaysian Ministry of Primary Industries, a total of approximately RM10 million has been allocated annually as subsidy in the form of farm inputs, training assistance, and farm-related equipment to support the development of the pepper industry in the country. However, most of this assistance is for new planting and excludes farm maintenance for matured pepper vines. The Board argues that the subsidy for farm maintenance is excluded because farmers should have generated sufficient income from their matured pepper vines to support the existing production cost of the farms. With the low pepper prices exacerbated by high input cost currently experienced, many pepper farmers have complained that it is difficult for them to sustain in the pepper cultivation venture without assistance or subsidy, especially from the government.

\subsubsection{Low Impact of Research, Development and Innovations (R\&D\&I)}

Research activity related to pepper in Sarawak was prompted by a serious outbreak of Phytophthora foot rot disease in 1952 (Sim \& Paulus, 2011). Subsequently, a more strategic effort was launched to develop several types of pepper cultivars that are more tolerant to diseases while having the potential to also exhibit other properties (Paulus et al., 2011). Apart from the Kuching variety (traditional cultivar), other cultivars developed by the earlier scientists include Semengok Perak (released in 1988), Semengok Emas (released in 1991), and Semengok Aman (released in 2006).

When the role of looking after the upstream pepper industry was surrendered officially from the Department of Agriculture Sarawak to the MPB in 2010, various new initiatives were enacted to improve the performance of the pepper industry in Malaysia. While focusing on strengthening the processing and marketing aspects of pepper, one of the notable R\&D\&I pursued by the Board (MPB) is the development of a bio-chemical fertilizer. However, there have been no significant outcomes regarding the effectiveness of the bio-chemical fertilizer in curbing the pepper from being attacked by the diseases, even though there are claims on the potential and positive effects of bio-chemical fertilizer on pepper (Yap, 2015). Solid empirical evidence has yet to be established, though a series of strong scientific evidence has been obtained from the pilot farm outcomes. Hence, most of the R\&D\&I activities still remain at fundamental and early-application 
research stages. In fact, a dedicated upstream R\&D\&I on pepper only commenced in early 2010 with very few capable research officers working with limited research facilities. Given this, effective and high-impact R\&D\&I initiatives on high-yielding and disease/pest-tolerant pepper cultivars, green farm technologies, as well as reliable pepper pole, which could replace the costly ironwood, should be developed to promote sustainable planting practices, effective integrated pests, and diseases management in the Malaysian pepper industry.

\subsubsection{Lack of Good Agricultural Practices (GAP)}

Despite consistent deployment of training and extension services over the years, there is no standard on Good Agricultural Practices (GAP) implementation at pepper farms, even though the GAP standard for pepper was approved on 19 January 2006 by the Standard for Industrial Research Institute (now known as SIRIM Berhad) (Eng \& Gumbek, 2007). This suggests that pepper farmers may not subscribe to GAP protocols in food production, which may jeopardise the quality and safety of the food crop produced. Pepper is an edible food, and in order not to tarnish the good reputation of Sarawak Pepper with pesticide residues and microbial contamination, strict rules to monitor food safety of pepper-related produce are crucially required.

\subsection{Challenges in the Downstream}

Despite being regarded as one of the most prized commodities in the world, the development of the pepper industry in Malaysia continues to be undermined by several forces at the downstream level. The section below highlights these forces:

\subsubsection{Low Domestic Consumption and Importation Issues}

Despite a surge in the demand for Sarawak Pepper in international markets, domestic demand and consumption for local peppers remain unsatisfactory. According to the statistics released by the MPB in 2017, domestic consumption of pepper ranges between 8,000 and 10,000 metric tonnes annually. On the other hand, the pepper industry in Malaysia is facing a threat of increasing import volumes mainly because imported pepper is cheaper than the locally produced pepper. Unlike India, Malaysia currently does not impose any import tariffs on the pepper imported into the country. This suggests that Malaysian pepper or Sarawak Pepper has to compete with pepper from other countries to fill the demand of local food manufacturers and other related industries. Recognizing this, the total domestic consumption released by the MPB may not reflect the actual consumption level of Malaysian pepper. In order to solve this problem, there is no alternative other than producing value added pepper in Malaysia to take into consideration on food safety and environmental-friendly production. This is to meet growing demand among buyers who are more environmental- and health-conscious in the years to come.

\subsubsection{Poor Investment in Downstream Activities}

The full potential of pepper downstream activities has yet to be exploited, and the private sector participation and investment have been minimal (MPB, 2017). Currently, downstream activities related to the industry are centred within the food-related industry, and almost no attention is given to exploring other possibilities, particularly in the pharmaceutical and cosmeceutical 
industries. In addition, there is no special tax incentive to support the development of downstream activities related to the industry. Likewise, institutional support for downstream R\&D is still lacking. There are only a couple of research officers working on certain aspects ranging from food to non-food applications of pepper, with very limited research facilities and infrastructure.

\subsubsection{High Demand Low Prices for Quality Pepper}

In line with the food safety requirements, the MPB continues to put greater emphasis on its purchasing activity, where the entire pepper purchasing activity must adhere to the Standard Operating Procedures (SPO) determined by the Board. According to the SOP, the Board only buys clean and quality pepper from the local farmers. In addition, farmers are advised to use and apply only those pesticides approved by the Pesticide Board. Prior to further cleaning and processing, purchased pepper is kept in clean warehouses. The Board also operates a Hazard Analysis and Critical Control Points $\left(\mathrm{HACCP}^{\dagger}\right)$-certified steam treatment plant. Based on the evidence presented, it was found that the Board is working hard to ensure constant production of quality Sarawak Pepper, but customers (pepper buyers) may demand cheaper prices as they compare Sarawak Pepper with the lower prices of imported pepper from other pepper-producing countries.

\subsubsection{Intense Competition}

The pepper industry is highly affected by the pricing factor due to keen competition from other producing countries, as larger producing countries tend to market their products at lower prices due to excessive volumes of lower quality produce compared with the stringent rule to produce high quality Sarawak Pepper in Malaysia. In addition, some of the importing countries have imposed tariffs on imported pepper, further impeding market access. The MPB has not implemented any new measures to minimise the import of pepper from other producing countries. Given this, when the prices of pepper in other producing countries are lower than the prices of local raw materials, importers prefer to import instead of using locally produced higher-priced pepper. The absence of such mechanism has directly caused Sarawak Pepper to become less competitive locally and in the global markets. On the other hand, Porter argues that competitive advantage can be achieved if products or services can be produced better or cheaper than rivals (Porter, 1985). However, given the large scale production of pepper in Vietnam and Indonesia in particular, while recognising some of the long outstanding fundamental issues faced by the pepper industry in Sarawak may appear to suggest that price competitive advantage in pepper industry cannot be achieved easily.

\section{PROSPECTS, STRATEGIES AND MANAGERIAL IMPLICATIONS}

In Malaysia, Sarawak is blessed with the suitable soil type and climate conditions for pepper cultivation. As the demand for pepper is predicted to increase in tandem with the rise of the

\footnotetext{
+ The Malaysian Certification Scheme for Hazard Analysis and Critical Control Point (HACCP) system is a management system in food industries for certification and surveillance activities of the HACCP system and provides formal recognition to food premises that have effectively implemented the HACCP system. Malaysian Pepper Board had obtained its HACCP-certificate in 2010 which guaranteed food safety of the pepper produced in Malaysia.
} 
world's population, the market potential for pepper both locally and globally will likely soar. Hence, the pepper industry should be strategically developed as the crop has great potential to be used to improve the socio-economics and livelihood of the rural farmers while generating additional export earnings. In fact, several fundamental challenges faced by the industry should be addressed holistically, strategically, and innovatively.

In particular, greater effort is required to increase the investment in downstream activities, whether in pharmaceutical, medicine, cosmetic, perfumery, or food industries. Malaysia has been involved in pepper trading activities since the formation of the Pepper Marketing Board (now known as MPB); however, the export performance as well as the growth and development of the industry have not seen significant drastic improvement. In fact, the pepper industry in Malaysia has reached a crossroads, and its future is uncertain if no serious, significant, and innovative improvements are made to the policy, structures, and strategies throughout the whole supply and value chains of the pepper industry. Without this, Malaysia will remain incapable of competing with other pepper producing countries. Malaysia cannot compete in terms of export prices of the commodity due to high production costs, even though Sarawak can produce a higher quality of pepper compared to other producing countries. Hence, in search of a higher demand for Sarawak Pepper, there is a need to constantly find a niche market and export only value-added pepper products instead of the commodity product of pepper in the international market. In addition, as the global market is moving towards sustainable development with greater awareness to ensure safety and cleanliness of food products, the pepper industry in Malaysia has no choice but to fully adopt the Good Agricultural Practices (GAP) in all pepper farms throughout the country, as this will ensure a high quality of pepper for the export market. Recognizing the challenges encountered by the industry both at the upstream and downstream levels as well as the future prospects of the pepper industry, the following strategies and directions are proposed for consideration.

\subsection{Increase Production for Quality Pepper}

Globally, the total average supply of pepper in the last five years was approximately 376,300 tonnes, while the demand is at an average of 426,900 tonnes (MPB, 2016a). This caused the price to increase significantly through 2015 . However, the supply of pepper has exceeded the demand since 2017 due to overproduction in Vietnam, Brazil, and China. This phenomenon eventually pushed prices down in 2019. Recognising this situation, Malaysia should move in a new direction by intensifying its efforts to produce more high-quality pepper for the export market, as Sarawak Pepper is priced much lower than the organic pepper in the high-end retail market. Hence, Malaysia should continue to increase pepper production up to 35,500 tonnes by 2020 while strengthening its productivity growth from $2.5 \mathrm{~kg} /$ vine to $3.0 \mathrm{~kg} / \mathrm{vine}$. In this respect, the effective application of Good Agricultural Practices by promoting sustainable production should be implemented, as this may lead to higher yield and productivity. However, the pepper industry is currently facing a low yield partly due to soil nutrient deficiencies. Hence, a soil fertility study should be conducted systematically to address the problem and to identify suitable counter measures and solutions.

\footnotetext{
‡ Sarawak Pepper is not organic pepper as farmers still use substantial amount of chemical inputs for production. An organic production is generally a production system that sustains the health of soil, ecosystem and people (IFOAM, 2020).
} 


\subsection{Promoting Youth Participation in Pepper Farming}

Rural youth are the future of food security; however, only a few young people see a future for themselves in agriculture or rural areas (Food and Agriculture Organization of United Nations [FAO], 2014). In the pepper industry, youth involvement is still low. Given its future prospects, rural youth should be encouraged to participate in pepper farming in a modern and a sustainable manner. Effective and specific programmes to encourage the youth to engage in planting new crops using improved technologies with better incentives provided to agropreneurs particularly for value-added eco-friendly (sometimes also termed as environmental-friendly by using reduced amount of chemicals inputs) Sarawak Pepper should be developed in Malaysia.

\subsection{Encouraging Alternative Farm Inputs}

Chemical fertilizers and pesticides may be effective, but the benefits come at a cost. Over the years, the cost of maintenance for pepper farms has increased steadily, causing the cost of production per vine to remain high. On the other hand, numerous reports have been published where certain chemical substances are not eco-friendly and pose considerable health threats to humans (Nicolopoulou-Stamati, Maipas, Kotampasi, Stamatis, \& Hens, 2016). In fact, regular usage of chemical substances may lower soil quality as well. Hence, the use of organic fertilizers and natural plant extracts should be promoted as an alternative because they are easy and costeffective. Consistent application may eventually bring down the overall production cost. Furthermore, simulation analysis carried out by Wong (2007) published in Khalid, Wong, \& Liwan (2009) had confirmed that promoting eco-friendingly pepper production (reduction in chemical inputs used) did not threathen the export competitiveness of pepper industry in Malaysia. On pepper poles, rather than using Belian, which is expensive and difficult to find, pepper planters can use living plant support for the pepper vine as an alternative. This is also to support a sustainable agriculture production method.

\subsection{Promoting Private Sector Participation}

Currently, the industry is dominated by smallholders who rely substantially on government assistance. On the other hand, the private sector participation in the industry is minimal, especially in the upstream level. Therefore, there is a need to attract private sector investment into venturing the both upstream and downstream activities in the industry, with relevant incentives such as offering double tax deductions. This would boost up domestic pepper demand besides allowing or encouraging the smallholders to strengthen the upstream activities. In addition, viewing pepper as a high-risk crop due to Phytophthora spp. and Fusarium spp., these main pepper-threatening diseases should be addressed systematically. More research and development strategies should be carried out to mitigate this problem to make the pepper cultivation venture more attractive to the private sectors.

\subsection{Strengthening Extension Services}

Due to the limited number of extension staff engaged, the effectiveness of the extension services attained in Malaysian pepper industry is minimal. To address this issue, the Technology Transfer Programme (TTP) should be conducted at the farm level for groups of pepper farmers in a particular area, thus optimising the extension officers' services. In addition, initiatives to develop 
relevant applications and videos related to the development and/or management of pepper farms should be strengthened and intensified. Technical staff should capitalise the use of modern technologies, including using applications developed to share and impact pepper farmers' knowledge.

\subsection{Intensifying $R \& D \& I$ Activities}

While focusing on the fundamental aspects of R\&D\&I on pepper, strategic initiatives should be undertaken to add value to pepper and pepper-based products, including improving the productivity, quality, and sustainability of the crop both at the upstream and downstream levels. Value-added pepper products, like pepper extracts and ground pepper, can minimise the effect of commodity pepper price fluctuation. Furthermore, venturing into this immense potential of the pepper extract market may significantly reduce the export of raw commodity pepper in the future.

In addition, R\&D\&I into new high-yielding, disease/pest-tolerant pepper cultivars, new planting practices, effective pest and disease control management, and the development of green farm technologies should be intensified. However, such efforts should be pursued strategically with bigger financial allocation from the government.

Within the same direction, even though producing pepper planting materials through tissue culture has entered a promising phase, work on identifying useful traits through DNA analysis should be continued by a capable research team. Strategic R\&D\&I initiatives that cover establishing a pepper genetic database, improvement of fertilizer quality, innovative pepper cultivation, development of a new pepper pole, production of quality planting material, better farm mechanisation, and commercialisation of R\&D outcomes should be continued and should become the key focus of MPB research initiatives.

\subsection{Establishing New Market Channels}

For the industry to remain competitive in the marketplace while minimising its price fluctuations, new distribution channels, like big super market stores, major distributors, and online marketing using e-commerce, should be the key focus to drive the brand name of Sarawak Pepper forward globally. New market outlets should be explored both in domestic and international markets to ensure the products stay close to consumers worldwide.

\subsection{Increasing Awareness on Food Safety}

Consistent education of consumers on the importance of prioritising food safety over price is needed. By increasing their awareness, consumers will have a better understanding of premium pepper products produced according to stringent international food safety requirements. The aim of applying Good Agricultural Practices (GAP) and Good Manufacturing Practices (GMP) will ensure that all processed peppers are guaranteed safe for consumption and free from any contamination. At the processing level, the MPB should continue to implement effective GMP to ensure food safety. In addition, to strengthen the quality of processed Sarawak Pepper, various international certification standards should be adopted in processing initiatives, including Halal certification and HACCP regulations. 


\subsection{Promoting Strategic Downstream Activities}

There is a need for greater downstream activities and bigger exports of downstream products while reducing the export of commodity pepper as raw materials. This approach will also minimise the role of intermediaries within the supply chains in the pepper market. Therefore, the emphasis should be on the need to produce high-quality pepper to meet the niche market.

Currently, pepper is widely used in the food industry, and the use of pepper in other industries, like pharmaceuticals and cosmetics, is still low. Given its potential, however, more downstream activities should be explored. Potential entrepreneurs should be identified, and relevant training should be developed and provided at a larger scale. In addition, strategic collaboration between domestic and international players should be enhanced. The establishment of a new Research and Development Complex in Semongok, Kuching, Sarawak should provide further support to the development of the pepper industry. Any new and potential discoveries should strengthen the downstream activities and create another platform for aspiring entrepreneurs and investors to exploit the new findings.

\section{CONCLUSIONS, LIMITATIONS AND FUTURE STUDIES}

Pepper trading has become a very competitive business internationally due to its stiff competition among producing countries. On the other hand, the cost to undertake pepper farming continues to rise. A review on the development and performance of the pepper industry in Malaysia revealed that the industry is facing great challenges both domestically and internationally, and if there is no serious commitment to address these challenges holistically, strategically, and innovatively, it may cause the industry to disappear very soon. Hence, to ensure the sustainability of the pepper industry as a whole and particularly the livelihood of the pepper community in Sarawak, it is important to acknowledge that when low pepper prices extend for a long period of time (5 to 10 years), the government must provide all the necessary support and assistance it can, especially in the form of production incentives, to ensure that the farmers will not switch crops but will remain in the pepper industry. In addition, to ensure the marketability of Sarawak Pepper, venturing into downstream products innovatively is the way forward. Hence, there is a need to transform traditional pepper cultivators into modern pepper entrepreneurs or agropreneurs capitalizing on modern and high-impact technology supported by strong and sustainable R\&D\&I initiatives. This will ensure the sustainability of Sarawak Pepper globally.

This paper does come with its limitations. Firstly, we build our study based on past documents and information. The outcomes and information gathered from the special programme conducted by the MPB was only confined to a small group of pepper farmers in Sarawak, and this may not represent the overall situation of the pepper industry in Malaysia. Secondly, the outcomes of the review do not build on any correlation or relationship approach. Hence, it is not possible to determine the extent to which each of these forces/challenges have impacted the industry. Recognizing this, future research should look into this possibility. 


\section{REFERENCES}

Amadeo, K. (2020, January 16). Government Subsidies (Farm, Oil, Export, Etc). US Economy and News. Retrieved from https:/www.thebalance.com/government-subsidies-definitionfarm-oil-export-etc-3305788

Awit, U. (2017). Pepper Production Costs. Malaysian Pepper Board, Kuching.

Awit, U. (2018). Report on Pepper Farm Attacked by Diseases. Malaysian Pepper Board, Kuching.

Chand, R., \& Phillip, L. M. (2001). Is WTO providing level playing field subsidies and support in agriculture. Economic and Political Weekly, 36(32), 3014-3016.

Chen, J. P. U., \& Mansel, E. L. (2017). 100 years of agricultural development in Sarawak. Kuching, Malaysia: Lee Ming Press Sdn Bhd.

Creswell, J. W., \& Plano Clark, V. L. (2007). Designing and conducting mixed methods research. Thousand Oaks, CA: Sage.

Dardak, R. A. (2015, February 4). Transformation of Agricultural Sector in Malaysia through Agricultural Policy. Taipei, Taiwan: Food and Fertilizer Technology Center for the Asian and Pacific Region. Retrieved from https://ap.fftc.org.tw/article/818

Department of Statistics, Malaysia. (2017). Statistical Yearbook 2017. Malaysia: Department of Statistics.

Eng, L., \& Gumbek, M. (2007, July 3-4). Contributions of R\&D on diseases and pests to the development of the pepper industry in Sarawak, Malaysia. Proceeding of the 2007 Conference on Plantation Commodities (pp. 170-179). Kuala Lumpur, Malaysia: Malaysian Cocoa Board.

Food and Agriculture Organization of the United Nations (FAO). (2014). Youth and Agriculture: Key Challenges and Concrete Solutions. Retrieved from https:/www.ifad.org/documents/38714170/39135645/Youth+and+agriculture_Key+chall enges+and+concrete+solutions/e803da0e-edc8-461b-961a-233a2dc61458.

Groenewald, T. (2004). A phenomenological research design illustrated. International Journal of Qualitative Methods, 3(3), 42-55.

Gulick, J. V. (2018, October 30-31). Crop Report-Pepper. Paper presented at the ESA Conference, Florence, Italy.

Haryani, N. (2016, August 2). Anugerah Harta Intelek Negara 2016. Berita Harian.

International Pepper Community (IPC). (2018a). Pepper Statistical Yearbook 2017. Retrieved from Jakarta: IPC.

International Pepper Community (IPC). (2018b). World Pepper Production by Major Pepper Producing Countries in 2018. Retrieved from Jakarta: IPC.

Janvry, A. D., \& Sadoulet, E. (2010). Agricultural growth and poverty reduction: Additional evidence. The World Bank Research Observer, 25(1), 1-20.

Khalid, A. R., Wong, S. K., \& Liwan, A. (2009). Competitiveness with sustainable agriculture: Win, lose or draw? International Journal of Economics and Management, 3(1), 87-99.

Khalid, A. R., Wong, S. K., \& Alias, R. (2007). Pepper industry. In M. A. Fatimah, R. A. Nik Mustapha, K. Bisant, \& M. A. Amin (Eds.), 50 years of Malaysian Agriculture: Transformational Issue, Challenges \& Direction (pp.442-473). Serdang, Malaysia: Penerbit Universiti Putra Malaysia.

Khew, C. Y., Lau, E. T., Evy, E. M., \& Haroun, M. S. (2015). Identification of suitable reference genes for gene expression study of black pepper (Piper Nigrum L). Focus on Pepper, 7(1), 59-72. 
Kueh, T. K. (1978). Pepper Foot Rot. Technical Bulletin, 2. Agriculture Resaerch Centre, Sarawak.

Kueh, T. K. (1979). Pests, diseases and disorders of black pepper in Sarawak. Kuching, Malaysia: Department of Agriculture Sarawak.

Lau, E. T., Hwang, S. S., Lily, E., \& Paulus, A. D. (2013). Discovery of genes related to disease resistance in Piper species. Focus on Pepper, 5, 29-40.

Malaysian Pepper Board. (2016a). Pepper Production by Countries. Kuching, Malaysia: MPB Strategic Planning Division.

Malaysian Pepper Board (MPB). (2016b). Annual Report of Malaysian Pepper Board. Kuching, Malaysia: Author.

Malaysian Pepper Board (MPB). (2017). Annual Report of Malaysian Pepper Board. Kuching, Malaysia: Author.

Malaysian Pepper Board (MPB). (2018a). Annual Report of Malaysian Pepper Board. Kuching, Malaysia: Author.

Malaysian Pepper Board (MPB). (2018b). Survey of Pepper Farmers in Sarawak. Kuching, Malaysia: MPB.

Manohara, D., Mulya, K., \& Wahyuno, D. (2004). Phytophthora disease on black pepper and the control measures. Focus on Pepper, 1, 37-49.

Ministry of Primary Industries and Commodities (MPIC). (2012). National Commodity Policy 2011-2020. Retrieved from Putrajaya: Ministry of Primary Industries and Commodities.

Nicolopoulou-Stamati, P., Maipas, S., Kotampasi, C., Stamatis, P., \& Hens, L. (2016, July 18). Chemical Pesticides and Human Health: The Urgent Need for a New Concept in Agriculture. Front Public Health. Retrieved from https:// doi:10.3389/fpubh.2016.00148

Ooi, T. C. (2019, July 16). Malaysia and Indonesia to jointly fight EU's palm oil ban at WTO. New Straits Times. Retrieved from https://www.nst.com.my/business/2019/07/504866 /malaysia-and-indonesia-jointly-fight-eus-palm-oil-ban-wto

Paulus, A. D. (2007). Development of superior genotypes and cultural practices for improving productivity of pepper in Sarawak, Malaysia: Progress, achievements and research needs. Proceeding of the 2007 Conference on Plantation Commodities (pp. 149-155). Kuala Lumpur, Malaysia: Malaysian Cocoa Board.

Paulus, A. D., Sim, S. L., Eng, L., Megir, G., \& Rosmah, J. (2011). Pepper Production Technology in Malaysia. Kuching, Malaysia: Malaysian Pepper Board and Department of Agriculture Sarawak.

Pemandu Associates. (2018). National Transformation Study for Plantation and Commodities Sector. Kuala Lumpur, Malaysia: Pemandu Associates.

Porter, M. E. (1980). Competitive Strategy: Techniques for Analysing Industries and Competitors. New York: Free Press.

Porter, M. E. (1985). Competitive Advantage: Creating and sustaining superior performance. New York: Free Press.

Rosli, A., Radam, A., \& Rahim, K. A. (2013). Technical efficiency of pepper farms in Sarawak, Malaysia: An application of Data Envelopment Analysis. International Journal of Business and Social Science, 4(7), 227-234.

Shafinah, K., Sahari, N., Sulaiman, R., Saif, A. F. M. S., \& Ikram, M. M. (2019, November 2527). m-Naslada: A mobile application for black pepper crop disease information. Paper presented at The 2nd Joint International Conference on Emerging Computing Technology and Sports (JICETS), Bandung, Indonesia. 
Sim, S. L., \& Paulus, A. D. (2011). Introduction. In K. F. Lai \& S. L. Sim (Eds.), Pepper Production Technology in Malaysia. Kuching, Malaysia: Malaysian Pepper Board.

Wong, S. K. (2007). Simulative impact of environmental friendly production method of Sarawak Pepper (Unpublished doctoral disseration), Universiti Putra Malaysia, Serdang, Malaysia.

Yap, C. A. (2015). Determinants of the efficiency and efficacy of bio-chemical fertilizer on the soil, yield and growth performance of black pepper. Journal of Advances in Agriculture, $4(3), 460-468$. 